\title{
Expression of vascular endothelial growth factor (VEGF) and its receptors in human endometrium throughout the menstrual cycle and in early pregnancy
}

\author{
N. Sugino, S. Kashida, A. Karube-Harada, S. Takiguchi and H. Kato \\ Department of Obstetrics and Gynecology, Yamaguchi University School of Medicine, \\ Minamikogushi 1-1-1, Ube 755-8505, Japan
}

\begin{abstract}
Immunohistochemistry for vascular endothelial growth factor (VEGF) and its receptors, fms-like tyrosine kinase (flt-1) and kinase insert domain-containing region (KDR), was performed on human endometrium obtained from patients with normal menstrual cycles, patients given oestrogen and progesterone, and women in early pregnancy. Intense immunostaining of VEGF was observed in both glandular epithelial and stromal cells during the midsecretory phase; the immunostaining intensity was increased by administration of oestrogen plus progesterone and strong immunostaining was observed in decidual cells of early pregnancy. In addition to the immunostaining in vascular endothelial cells, strong KDR immunostaining was observed in glandular epithelial cells and in decidualized stromal cells induced by administration of oestrogen
\end{abstract}

plus progesterone, whereas flt-1 immunostaining was negligible. Strong immunostaining for flt-1 and KDR was found in both vascular endothelial cells and decidual cells in early pregnancy. Endometrial stromal cells isolated from proliferative phase endometrium were incubated with oestrogen $\left(1^{-8} \mathrm{~mol} \mathrm{I}^{-1}\right)$ and medroxyprogesterone acetate (MPA; $10^{-6} \mathrm{~mol} \mathrm{I}^{-1}$ ) for 18 days to study the regulation of VEGF, flt-1 and KDR in endometrial stromal cells by oestrogen and progesterone. Expression of VEGF and KDR mRNAs was increased significantly by oestrogen and MPA, accompanied by decidualization, whereas flt-1 mRNA expression was not affected. In conclusion, VEGF and its receptors may play important roles in implantation and maintenance of pregnancy.

\section{Introduction}

Angiogenesis is important for development and differentiation of human endometrium, which are necessary for implantation, as well as for maintenance of pregnancy (Klauber et al., 1997; Smith, 1998; Hickey and Fraser, 2000). Vascular endothelial growth factor (VEGF) is a protein that has the potential to play a dynamic role in the regulation of vascular endothelial growth, angiogenesis and vascular permeability (Ferrara and Davis-Smyth, 1997; Kashida et al., 2001). Recent studies have shown that VEGF is expressed in the endometrium and probably participates in the increased angiogenesis and vascular permeability necessary for successful implantation (Chakraborty et al., 1995; Das et al., 1997). However, studies on the change in endometrial VEGF expression during the menstrual cycle have not given consistent results and, in particular, expression of VEGF in endometrial stromal cells is controversial. It is reported that diffuse and intense immunostaining of VEGF in the stroma is found during the secretory phase but not during the proliferative phase (Greb et al., 1995; Shifren et al., 1996). A recent in vivo study in monkeys showed that VEGF immunostaining in endometrial stromal cells was increased by progesterone treatment (Greb et al., 1997). In

Email: obgyn@po.cc.yamaguchi-u.ac.jp contrast, Charnock-Jones et al. (1993) and Li et al. (1994) reported that VEGF mRNA signals in in situ hybridization or VEGF immunostaining in the stroma were higher in the proliferative phase than in the secretory phase. In addition, there are some reports that VEGF expression showed no significant change in the stroma during the menstrual cycle (Torry et al., 1996; Lau et al., 1998; Macpherson et al., 1999). Thus, regulation of stromal VEGF expression by ovarian steroids is still unclear.

VEGF activities are mediated by two known receptors: the fms-like tyrosine kinase (flt-1: VEGFR-1) and the kinase insert domain-containing region (KDR: VEGFR-2), which are generally found on vascular endothelial cells. Recent studies using immunohistochemistry have shown that flt-1 and KDR are localized mainly to vascular endothelial cells in human endometrium (Meduri et al., 2000); however, expression was also observed in the glandular epithelium and stroma (Nayak et al., 2000; Möller et al., 2001). In addition, mRNA expression for the two receptors was found in both epithelial and stromal cells isolated from human endometrium (Krüssel et al., 1999). However, little is known about the expression and regulation of VEGF receptors in human endometrium. Therefore, the aim of the present study was to investigate the localization and hormonal regulation of VEGF, flt- 1 and KDR in human endometrium. For this purpose, endometrium obtained 
from patients with normal menstrual cycles, from patients who had been treated with oestrogen and progesterone, and from women in early pregnancy, were used. The regulation of VEGF, flt-1 and KDR by ovarian steroids was examined further using isolated endometrial stromal cells in vitro.

\section{Materials and Methods}

This project was reviewed and approved by the committee on investigations involving human subjects of Yamaguchi University School of Medicine. Informed consent from each patient was obtained before collection of any tissue samples for this study.

\section{Materials}

Phenol red-free Dulbecco's modified Eagle's medium (DMEM) and glutamine were purchased from ICN Biomedicals Inc. (Aurora, OH). Streptomycin, penicillin, $1 \times$ trypsin-EDTA, deoxynucleotide triphosphates and Moloney murine leukaemia virus reverse-transcriptase were from Life Technologies Inc. (Grand Island, NY). Collagenase, medroxyprogesterone acetate (MPA) and oestradiol were from Sigma Chemical Co. (St Louis, MO). Fetal calf serum (FCS) was from PAA Laboratories $\mathrm{GmbH}$ (Linz). Tissue flasks and nylon mesh were from Becton Dickinson Co. (Franklin Lakes, NJ). Random Hexamer and Taq DNA polymerase were from Perkin-Elmer Co. (Foster City, CA). $[\alpha-$ $\left.{ }^{32} \mathrm{P}\right]$ deoxycytidine triphosphate (dCTP) was from Amersham (Arlington Heights, IL). Isogen was from Wako Pure Chemical Industries Ltd (Osaka).

\section{Tissue samples}

Endometrial tissues were obtained from patients aged 39-49 years who were undergoing hysterectomy for myoma uteri. As patients with submucous myoma were excluded from the study, endometrial samples were not close to leiomyoma. All tissue samples used in this study were shown to be histologically normal. Endometrial samples from patients with normal menstrual cycles were classified into five different groups according to the criteria of Noyes et al. (1950): early proliferative phase (days 4-7), mid- to late proliferative phase (days 8-14), early secretory phase (days 15-18), mid-secretory phase (days 19-23) and late secretory phase (days 24-28). Three women received oral administration of ethynyloestradiol (0.05 mg) plus norgestrel (0.5 mg) (Planovar; Weis-Ezai Co. Ltd, Tokyo) daily for 7-10 days from the mid-luteal phase onwards to avoid the onset of menstruation at surgery. Gestational endometria were obtained from three women undergoing artificial (surgical) abortion at weeks 6-8 of gestation.

\section{Immunohistochemistry}

Immunohistochemical study was performed on three different tissue samples from each of five stages of the menstrual cycle, three patients given oestrogen and progesterone, and three women in the early stages of pregnancy. Endometrial tissues were fixed in Carnoy solution (ethanol:chloroform:glacial acetic acid, 6:3:1), embedded in paraffin wax and cut into sections (4 $\mu \mathrm{m}$ thickness). The tissue sections were deparaffinized in xylene and dehydrated in a graded series of ethanol. Immunohistochemistry for VEGF and flt-1 was performed with a peroxidase-anti-peroxidase method (DAKO PAP kit; DAKO Japan Co. Ltd, Tokyo) using rabbit anti-human VEGF polyclonal antibodies (RB-222-p; Neomarkers, Inc., Union City, CA) or rabbit anti-human flt-1 polyclonal antibodies (C-17, sc-316; Santa Cruz Biotechnology Inc., Santa Cruz, CA), as reported by Sugino et al. (2000a). After inhibition of endogenous peroxidase activity with $0.3 \%(\mathrm{v} / \mathrm{v}) \mathrm{H}_{2} \mathrm{O}_{2}$ for $50 \mathrm{~min}$, the sections were incubated with $10 \%(\mathrm{v} / \mathrm{v})$ normal swine serum for $10 \mathrm{~min}$ at room temperature to avoid nonspecific binding. The sections were incubated with the primary antibodies at a dilution of $1: 50$ in PBS-BSA (1\% $(\mathrm{w} / \mathrm{v})$ ) overnight at $4^{\circ} \mathrm{C}$. After three washes with PBS for 5 min each, the sections were incubated with swine antirabbit immunoglobulin for $30 \mathrm{~min}$ at room temperature, washed three times with PBS for 5 min each, and reacted with rabbit-PAP for $40 \mathrm{~min}$ at room temperature. Immunohistochemistry for KDR was performed with a streptavidinbiotin-peroxidase complex method (SAB-PO kit; Nichirei Co. Ltd, Tokyo) using mouse anti-human KDR monoclonal antibodies (A-3, sc-6251; Santa Cruz Biotechnology Inc.) as reported by Sugino et al. (2000a). After inhibition of endogenous peroxidase activity with $0.3 \%(\mathrm{v} / \mathrm{v}) \mathrm{H}_{2} \mathrm{O}_{2}$ for $50 \mathrm{~min}$, the sections were incubated with $10 \%$ (v/v) normal rabbit serum for $10 \mathrm{~min}$ at room temperature to avoid nonspecific binding. The sections were incubated with the primary antibody at a dilution of $1: 50$ in PBS-BSA (1\% $(\mathrm{w} / \mathrm{v})$ ) overnight at $4{ }^{\circ} \mathrm{C}$. After three washes with PBS for 5 min each, the sections were incubated with biotinylated rabbit anti-mouse immunoglobulin for $10 \mathrm{~min}$ at room temperature, washed three times with PBS for $5 \mathrm{~min}$ each, and reacted with peroxidase-conjugated streptavidin for $5 \mathrm{~min}$ at room temperature. Peroxidase activity was visualized by incubating the sections with 3,3'diaminobenzidine-4-HCl (Nacalai Tesque Co. Ltd, Tokyo) in 0.05 mol Tris- $\mathrm{HCl}$ buffer $\mathrm{I}^{-1}(\mathrm{pH} 7.6)$ containing $0.01 \%$ (v/v) $\mathrm{H}_{2} \mathrm{O}_{2}$ for 2-3 min. For controls, sections were incubated with normal rabbit serum for VEGF and flt-1, or normal mouse serum for KDR, or the anti-flt-1 antibody was pre-absorbed with an excess of flt- 1 blocking peptide (sc316p; Santa Cruz Biotechnology Inc.) overnight at $4^{\circ} \mathrm{C}$. In addition, the specificities of the antibodies for VEGF, flt-1 and KDR have been established by western blotting and immunoprecipitation performed by the manufacturers. Counterstaining was performed with Meyer's haematoxylin.

\section{Endometrial stromal cell isolation and cell culture}

Human endometrium was obtained at hysterectomy from patients with normal menstrual cycles. As the cases with submucous myoma were excluded from the study, 
endometrial samples were not close to leiomyoma. All tissue samples used in this study were histologically normal. Proliferative phase endometrium, which was diagnosed histologically according to the criteria of Noyes et al. (1950), was used for cell culture. Tissue samples were washed with phenol red-free DMEM containing $4 \mathrm{mmol}$ glutamine $\mathrm{I}^{-1}$, $50 \mathrm{mg}$ streptomycin $\mathrm{I}^{-1}$ and $5 \times 10^{4} \mathrm{U}$ penicillin $\mathrm{I}^{-1}$, and were minced into small pieces of $<1 \mathrm{~mm}^{3}$. Endometrial stromal cells were isolated as reported by Sugino et al. (2000b). In brief, after the enzymatic digestion of minced tissues with $0.2 \%(\mathrm{w} / \mathrm{v})$ collagenase in a shaking waterbath for $2 \mathrm{~h}$ at $37^{\circ} \mathrm{C}$, stromal cells were separated by filtration through a $70 \mu \mathrm{m}$ nylon mesh. The filtrates were washed three times and the number of viable cells was counted by trypan blue exclusion. The homogeneity of the stromal cell preparation was verified by immunocytochemistry for the stromal-reacting antibody (vimentin) and $>98 \%$ of the cells were vimentin positive (data not shown). Cells were seeded at $10^{5}$ cells $\mathrm{cm}^{-2}$ in $75 \mathrm{~cm}^{2}$ tissue culture flasks and incubated in phenol redfree DMEM containing glutamine, antibiotics and 10\% (v/v) dextran-coated charcoal-stripped FCS at $37^{\circ} \mathrm{C}, 95 \%$ air and $5 \% \mathrm{CO}_{2}$. At confluence, cells were trypsinized by $1 \times$ trypsin-EDTA and subcultured in $25 \mathrm{~cm}^{2}$ tissue culture flasks. At approximately $80 \%$ confluence after first passage, the cell culture medium was changed to phenol red-free DMEM supplemented with glutamine, antibiotics and $2 \%$ $(\mathrm{v} / \mathrm{v})$ stripped FCS, with or without oestradiol $\left(10^{-8} \mathrm{~mol} \mathrm{I}-1\right)$ plus MPA $\left(10^{-6} \mathrm{~mol} \mathrm{I}^{-1}\right)$. The endometrial stromal cells were incubated for 18 days at $37^{\circ} \mathrm{C}$ in $95 \%$ air and $5 \% \mathrm{CO}_{2}$ to induce decidualization, as reported by Sugino et al. (2000b). The medium was changed every 2 days. A single incubation was performed in triplicate on cells from a single hysterectomy sample. The samples from three individuals were used and, hence, three different incubations were performed.

\section{Reverse transcription-polymerase chain reaction ( $R T-P C R$ )}

Total RNA was isolated from endometrial stromal cells with Isogen by the method provided by the manufacturer. For mRNA analysis, RT-PCR was performed as reported by Sugino et al. (1998) with the oligonucleotide primers for VEGF (5'-CACATAGGAGAGATGAGCTTC-3' and $5^{\prime}$-CCGCCTCGGCTTGTCACAT-3'), flt- 1 (5'-CTAGGATCCGTGACTTATTTTTTCTCAACAAGG-3' and 5'-CTCGAATTCAGATCTTCCATAGTGATGGGCTC-3') and KDR (5'-CGTGGATCCACCAAAGGGGCACGATTCCGTC - $3^{\prime}$ and 5'-CTCGAATTCTGTAACAGATGAGATGCTCCAAGG-3') designed by Athanassiades et al. (1998). Direct sequence analyses of the PCR products were performed for sequence verification. Two oligonucleotide primers (5'-CTGAAGGTCAAAGGGAATGTG-3' and 5'-GGACAGAGTCTTGATGATCTC-3') were used to amplify ribosomal protein L19 as an internal control (Sugino et al., 1998). In brief, $3 \mu \mathrm{g}$ total RNA was reverse-transcribed at $42^{\circ} \mathrm{C}$ in a reaction mixture (single-strength PCR buffer, $2.5 \mathrm{mmol}$ deoxynucleotide triphosphates $\mathrm{I}^{-1}, 5 \mathrm{\mu mol}$ random hexamer primer $\mathrm{I}^{-1}$, $1.5 \mathrm{mmol} \mathrm{MgCl} \mathrm{I}^{-1}$ and $200 \mathrm{U}$ Moloney murine leukaemia virus reverse transcriptase). The reverse-transcribed product was divided into equal aliquots in two tubes for VEGF, flt-1 or KDR primers, and L19 primers, and PCR was performed. For PCR amplification, a mixture containing the oligonucleotide primers $(50 \mathrm{pmol}),\left[\alpha-{ }^{32} \mathrm{P}\right] \mathrm{dCTP}(2 \mu \mathrm{Ci}$ at $3000 \mathrm{Ci} \mathrm{mmol}^{-1}$ ) and Taq DNA polymerase (2.5 U) was added to each reaction. Amplification was carried out for 25 cycles consisting of $94^{\circ} \mathrm{C}(1 \mathrm{~min}), 57^{\circ} \mathrm{C}(1 \mathrm{~min})$ and $72^{\circ} \mathrm{C}$ (1 min) for VEGF, 28 cycles consisting of $94^{\circ} \mathrm{C}(1 \mathrm{~min}), 60^{\circ} \mathrm{C}$ ( $1 \mathrm{~min})$ and $72^{\circ} \mathrm{C}(1 \mathrm{~min})$ for flt- 1 , and 25 cycles consisting of $94^{\circ} \mathrm{C}(1 \mathrm{~min}), 60^{\circ} \mathrm{C}(1 \mathrm{~min})$ and $72^{\circ} \mathrm{C}(1 \mathrm{~min})$ for $\mathrm{KDR}$, followed by $10 \mathrm{~min}$ of final extension at $72^{\circ} \mathrm{C}$ in a programmed temperature control system PC-800 (ASTEC, Fukuoka). The predicted sizes of the PCR-amplified products were $98 \mathrm{bp}$ for VEGF121, $228 \mathrm{bp}$ for VEGF165, 230 bp for flt-1, 209 bp for KDR and 194 bp for L19. A linear curve was plotted using number of cycles of amplification versus densitometric values of the PCR products and measured with a BAS2000 (Fuji Photo Film Co., Tokyo). The optimal number of cycles for amplification that fitted within the linear range was chosen for each set of primers of VEGF, flt-1, KDR and L19 (data not shown). Reaction products were separated by electrophoresis on an $8 \%(\mathrm{w} / \mathrm{v})$ polyacrylamide non-denaturing gel. After autoradiography, band intensities were analysed using a bioimaging analyser BAS2000. For quantification, the densities of VEGF, flt-1 and KDR were normalized to that of the internal control L19.

\section{Statistical analysis}

Data were examined by ANOVA and Student's $t$ test. Differences were considered significant at $P<0.05$.

\section{Results}

\section{VEGF immunohistochemistry}

During the menstrual cycle, VEGF immunostaining was observed in both glandular epithelial cells and stromal cells, with the highest intensity during the mid-secretory phase (Fig. 1a,b). At the premenstruation stage, the glandular immunostaining intensity decreased (data not shown). Endometrium from patients who had been treated with oestrogen and progesterone was used to study the regulation of VEGF expression by oestrogen and progesterone. The immunostaining intensity increased in the patients who received oestrogen and progesterone, especially in the stromal cells associated with decidualization (Fig. 1c). Decidual cells in early pregnancy also showed strong immunostaining (Fig. 1d).

\section{flt-1 immunohistochemistry}

flt-1 immunostaining of vascular endothelial cells was negligible during the entire menstrual cycle except for 

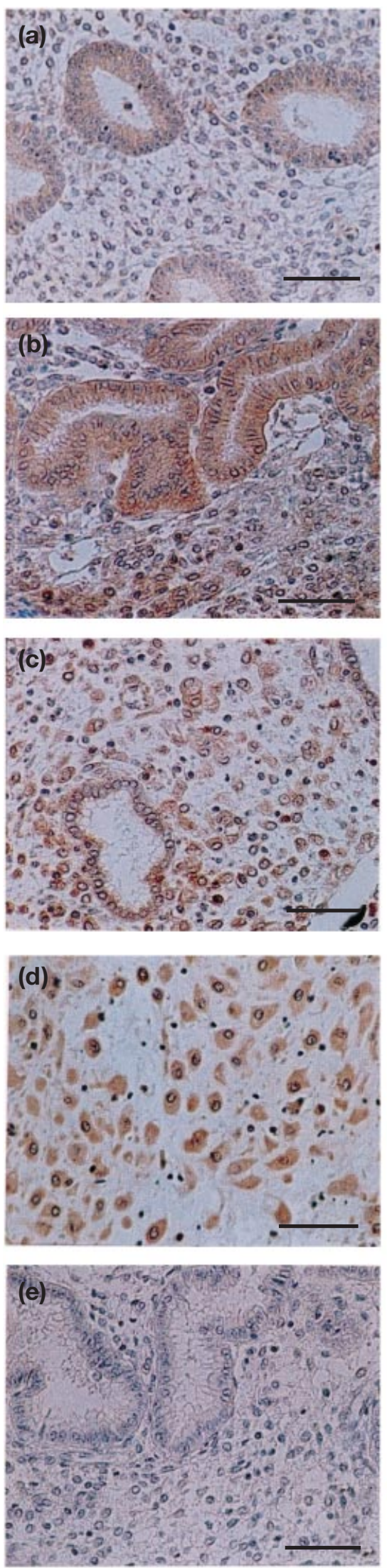
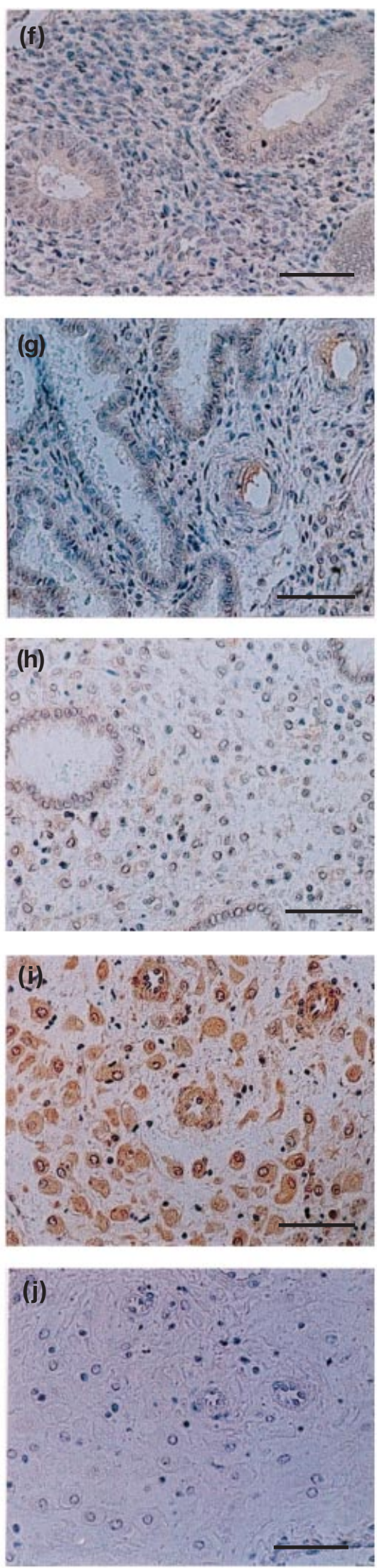
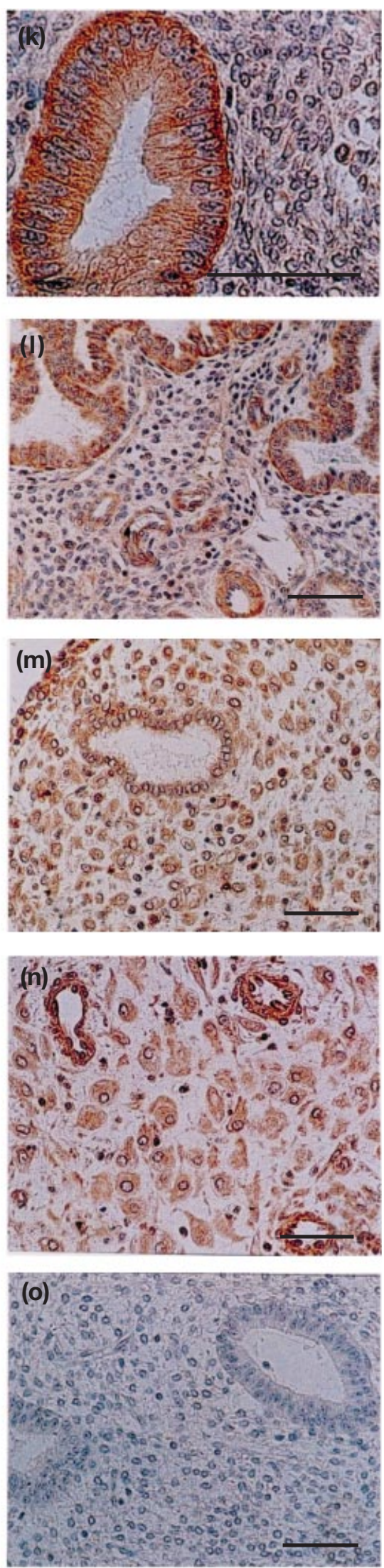

Fig. 1. For legend see facing page. 
Table 1. Summary of the immunohistochemical experiments identifying VEGF, flt-1 and KDR in human endometrium

\begin{tabular}{|c|c|c|c|c|c|c|c|}
\hline & \multicolumn{2}{|c|}{ Proliferative phase } & \multicolumn{3}{|c|}{ Secretory phase } & \multirow{2}{*}{$\begin{array}{c}\text { Treatment with } \\
\text { oestrogen } \\
\text { and progesterone }\end{array}$} & \multirow[b]{2}{*}{ Early pregnancy } \\
\hline & Early & Mid- to late & Early & Mid- & Late & & \\
\hline \multicolumn{8}{|c|}{ Epithelium } \\
\hline VEGF & + & + & + & ++ & - & ++ & ++ \\
\hline flt-1 & - & - & - & - & - & - & - \\
\hline KDR & +++ & +++ & ++ & +++ & +++ & +++ & +++ \\
\hline \multicolumn{8}{|l|}{ Stroma } \\
\hline VEGF & + & + & + & ++ & + & +++ & +++ \\
\hline flt-1 & - & - & - & - & - & - & +++ \\
\hline KDR & - & - & + & + & + & +++ & +++ \\
\hline \multicolumn{8}{|c|}{ Blood vessel } \\
\hline VEGF & - & - & - & - & - & - & + \\
\hline flt-1 & - & - & - & - & - & - & +++ \\
\hline KDR & + & + & + & ++ & ++ & ++ & +++ \\
\hline
\end{tabular}

VEGF: vascular endothelial growth factor; flt-1: fms-like tyrosine kinase; KDR: kinase insert domain-containing region.

Relative intensities of signals: from + (weakly positive) to +++ (strongly positive). -: no signal.

strong immunostaining in early pregnancy (Fig. 1i). Immunostaining for flt-1 in glandular epithelial cells and stromal cells was negligible during the menstrual cycle (Fig. $1-f, g)$ and in the endometrium of patients given oestrogen and progesterone (Fig. 1h). However, decidual cells in early pregnancy showed strong immunostaining (Fig. 1i). No flt-1 immunoreactivity was observed in the decidua after preabsorption of the anti-flt-1 antibody with an excess of flt-1 blocking peptide (Fig. 1j).

\section{KDR immunohistochemistry}

Immunostaining for KDR was observed in endothelial cells and smooth muscle cells of blood vessels during the menstrual cycle and in early pregnancy (Fig. 1I,n). Strong immunostaining was also detected in glandular epithelial cells in all stages of endometrium studied (Fig. $1 \mathrm{k}, \mathrm{l}$ ). In contrast, negligible immunostaining was observed in the stroma during the proliferative phase (Fig. $1 \mathrm{k}$ ), but weak and diffuse immunostaining was found in the stroma during the secretory phase (Fig. 1I). The immunostaining intensity increased in decidualized stromal cells of the endometrium treated with oestrogen and progesterone (Fig. 1m). Decidual cells in early pregnancy showed strong immunostaining (Fig. 1n).

These observations for VEGF, flt-1 and KDR are summa- rized (Table 1). There was little variation in the tissue samples used in this study.

\section{$R T-P C R$}

From the results of the immunohistochemistry, it was decided to examine the effect of decidualization on expression of VEGF and its receptors in endometrial stromal cells. Endometrial stromal cells isolated from proliferative phase endometrium were cultured in the presence or absence of oestradiol $\left(10^{-8} \mathrm{~mol} \mathrm{I}^{-1}\right)$ and MPA $\left(10^{-6} \mathrm{~mol} \mathrm{I}-1\right)$ for 18 days, reported by Sugino et al. (2000b) to induce decidualization by oestrogen and progesterone. Autoradiographs of RT-PCR for mRNA expression of VEGF, KDR and flt-1 are shown (Figs 2, 3 and 4, respectively). In vitro decidualization by oestradiol and MPA was confirmed by expression of insulin-like growth factor-binding protein-1 (IGFBP-1) mRNA, a specific marker of decidualization, as reported by Sugino et al. (2000b) (data not shown).

Four VEGF splice variants of 121, 165, 189, and 206 amino acids have been identified in human tissues (Ferrara and Davis-Smyth, 1997). RT-PCR analysis showed that the bands corresponding to VEGF121 and VEGF165 were in the isolated endometrial stromal cells (Fig. 2). The mRNA expression of both isoforms of VEGF was increased significantly by incubation with oestradiol and MPA (Fig. 2).

Fig. 1. Immunohistochemical staining for (a-e) vascular endothelial growth factor (VEGF), ( $f-j)$ fms-like tyrosine kinase (flt-1) and (k-o) kinase insert domain-containing region $(K D R)$ in human endometrium from the proliferative phase $((a)$ late proliferative phase; $(\mathfrak{f}, \mathrm{k})$ midproliferative phase), the mid-secretory phase $(b, g, l)$, the patients given oestrogen plus progesterone $(c, h, m)$, and early pregnancy $(d, l, n)$. (e) Mid-secretory phase; (j) early pregnancy; and (o) late proliferative phase are negative controls for VEGF, flt-1 and KDR, respectively. No VEGF and KDR immunostaining was seen in the control section $(\mathrm{e}, \mathrm{o})$ and no flt-1 immunostaining was observed after pre-absorption of the anti-flt-1 antibody with an excess of flt-1 blocking peptide (j). The negative controls were similar regardless of whether normal rabbit serum or normal mouse serum was used. Scale bars represent $50 \mu \mathrm{m}$. 

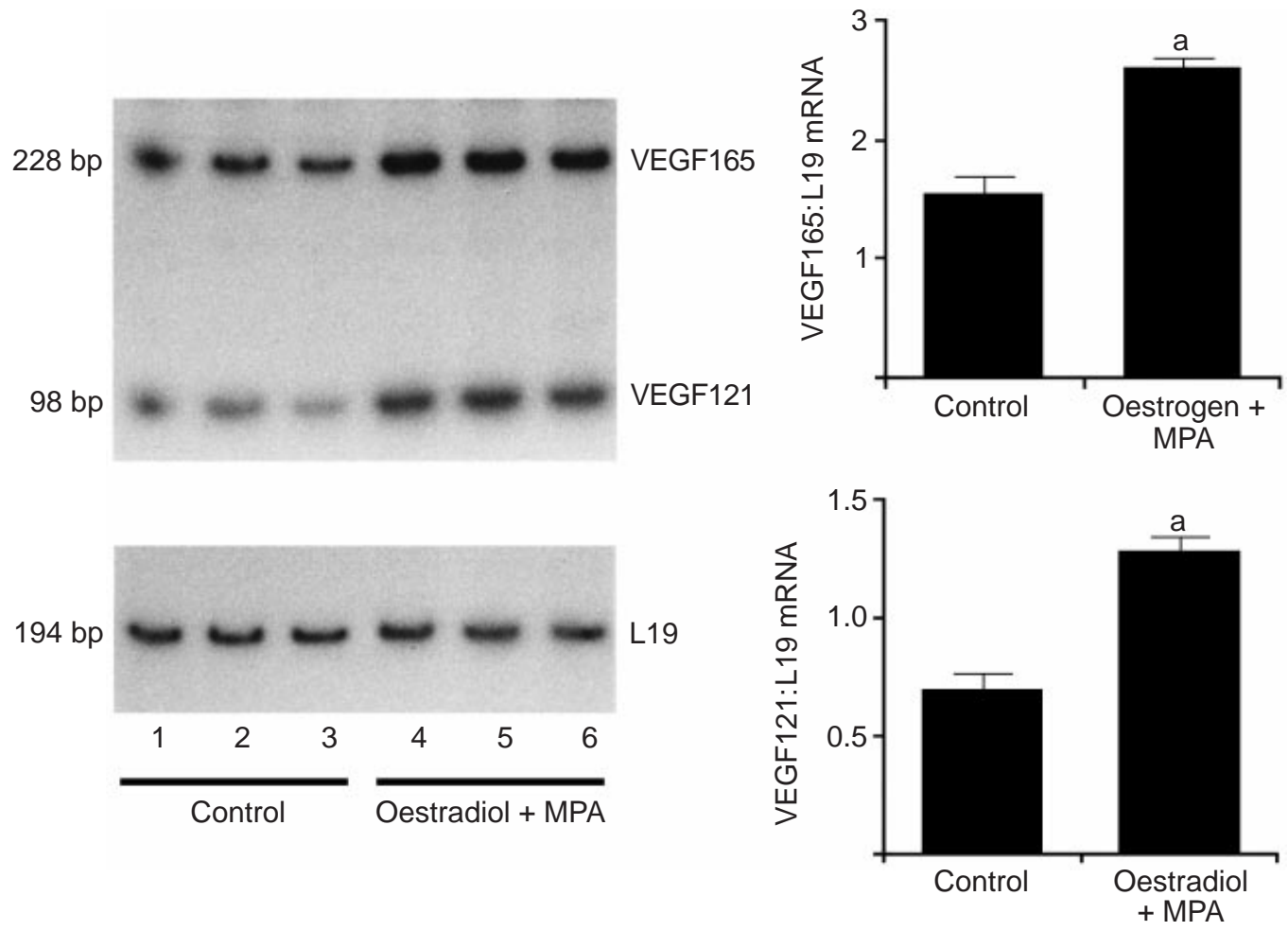

Fig. 2. Effects of oestrogen and progesterone on expression of vascular endothelial growth factor (VEGF) mRNA in human endometrial stromal cells in vitro. Endometrial stromal cells isolated from proliferative phase endometrium were incubated in the presence (lanes 4, 5 and 6) or absence (lanes 1, 2 and 3) of oestradiol $\left(10^{-8} \mathrm{~mol} \mathrm{I}^{-1}\right)$ and medroxyprogesterone acetate (MPA: $\left.10^{-6} \mathrm{~mol} \mathrm{l}^{-1}\right)$ for 18 days. After incubation, total RNA was isolated and mRNA content was determined by RT-PCR. A single incubation was performed in triplicate on cells from a single hysterectomy sample. The tissue samples from three individuals were used and, hence, three different incubations were performed. Each lane is from a culture derived from a single individual. The intensity of the signals of VEGF165 or VEGF121 was normalized to that of the internal control L19. The quantification data (the ratio of VEGF165 or VEGF121 to L19) represent the mean \pm SEM of three different samples. ${ }^{a} P<0.01$ versus control.

Expression of KDR and flt-1 mRNA was also detected in the isolated endometrial stromal cells, and the treatment with oestradiol and MPA increased expression of KDR mRNA, but not flt-1 mRNA, significantly (Figs 3 and 4).

\section{Discussion}

The results of the present study indicate that during the normal menstrual cycle VEGF immunostaining of both glandular epithelial cells and stromal cells increased during the mid-secretory phase compared with the proliferative phase. A number of reports have shown that epithelial VEGF expression is highest during the mid-secretory phase and is probably under the control of ovarian steroids (Charnock-Jones et al., 1993, 2000; Li et al., 1994; Greb et al., 1995; Shifren et al., 1996; Torry et al., 1996; Macpherson et al., 1999), whereas other workers have reported no significant change during the menstrual cycle (Möller et al., 2001) or high expression at the onset of menstruation (Graubert et al., 2001). However, results on stromal VEGF expression have been more controversial. Therefore, in the present study, endometrium from patients who had been treated with oestrogen and progesterone was used and, in addition, isolated endometrial stromal cells were cultured with oestrogen and progesterone. Our findings indicate that oestrogen and progesterone increased not only VEGF immunostaining in stromal cells in vivo but also expression of VEGF mRNA in isolated endometrial stromal cells in vitro accompanied by decidualization. These findings are consistent with previous reports showing that VEGF expression is upregulated by oestrogen and progesterone in endometrial stromal cells (Shifren et al., 1996; Huang et al., 1998; Lebovic et al., 2000). In the decidua of early pregnancy, strong VEGF expression in decidual cells and strong flt- 1 and KDR expression in vascular endothelial cells were found. The presence of VEGF and its receptors has been reported in periimplantation uteri in mice (Chakraborty et al., 1995). Collectively, it is likely that VEGF contributes to successful implantation and maintenance of pregnancy through the 

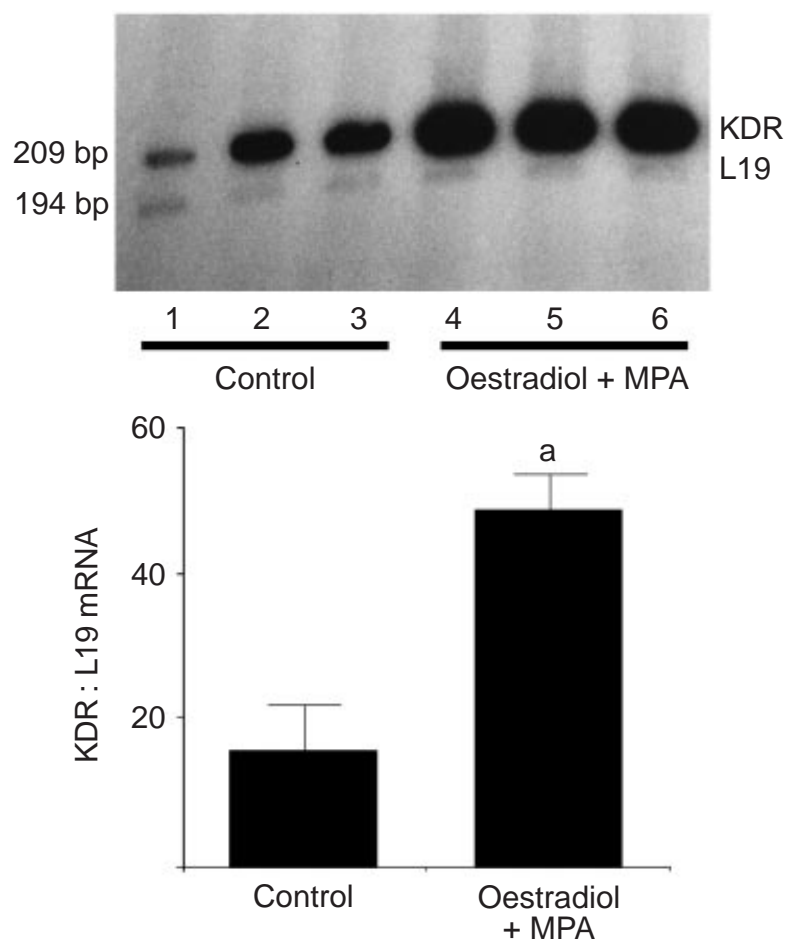

Fig. 3. Effects of oestrogen and medroxyprogesterone acetate (MPA) on expression of kinase insert domain-containing region (KDR) mRNA in human endometrial stromal cells in vitro. Expression of KDR mRNA was examined by RT-PCR using the same total RNA as in Fig. 2. The quantification data (the ratio of KDR:L19) represent the mean \pm SEM. ${ }^{\text {a }} P<0.01$ versus control.

increase in vascular permeability or the formation of the dense vascular network in the decidua.

The present study also showed intense KDR immunostaining in glandular epithelial cells during the menstrual cycle; this finding is consistent with reports by Möller et al. (2001) and Meduri et al. (2000). Significant KDR immunostaining was observed in the stroma during the secretory phase, especially in the decidualized stromal cells after treatment with oestrogen and progesterone. The immunohistochemical findings in the stroma are supported by the RT-PCR analysis, which showed that KDR mRNA content in the isolated endometrial stromal cells was increased by oestrogen and progesterone treatment. In contrast, Nayak et al. (2000) demonstrated immunohistochemical KDR expression in the stroma during the premenstrual phase and that progesterone suppresses stromal KDR expression in macaque endometrium. In addition, Graubert et al. (2001) demonstrated high expression of KDR and flt-1 mRNAs during the menstrual phase, and Krüssel et al. (1999) reported that KDR and flt-1 mRNAs were present at almost constant values throughout the menstrual cycle. In contrast to $\mathrm{KDR}$, immunostaining for flt- 1 in glandular epithelial cells and stromal cells was negligible during the menstrual cycle in the present study, whereas flt- 1 immunostaining in epithelial and stromal cells has been observed in
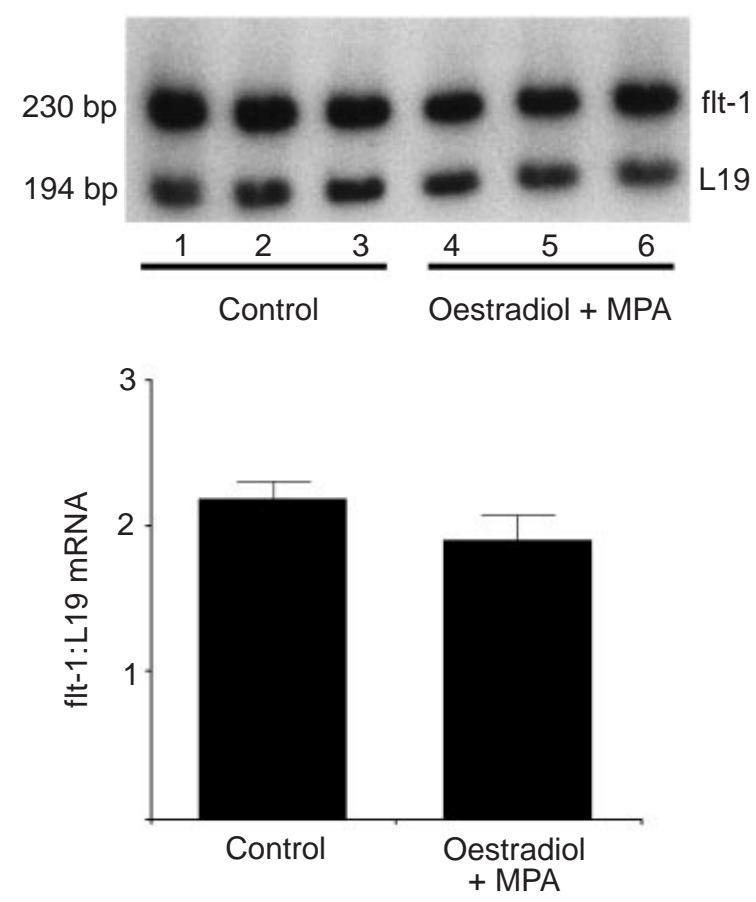

Fig. 4. Effects of oestrogen and medroxyprogesterone acetate (MPA) on expression of fms-like tyrosine kinase (flt-1) mRNA in human endometrial stromal cells in vitro. Expression of flt-1 mRNA was examined by RT-PCR using the same total RNA as in Fig. 2. The quantification data (the ratio of flt-1:L19) represent the mean \pm SEM.

other studies (Meduri et al., 2000; Möller et al., 2001). Thus, the results on flt- 1 and KDR expression in the human endometrium are still controversial. It is hard to explain the difference, but it may be due to differences in experimental technique, sample preparation and the antibodies used.

KDR expression in endometrial stromal cells was increased by oestrogen and progesterone in vivo and in vitro, and strong KDR expression was observed in decidual cells. As the gene promoter of human KDR has the binding sites for glucocorticoid receptor/progesterone receptor (GR/PR) but not for oestrogen receptor (Patterson et al., 1995), KDR appears to be under the control of progesterone. In contrast, stromal flt-1 expression was not affected by oestrogen and progesterone, whereas flt- 1 was expressed strongly in decidual cells. Decidual flt-1 expression may be influenced by a local factor derived from the conceptus, as there is a report suggesting the involvement of a conceptus factor to complete the decidualization process of endometrial stromal cells in primates (Tarantino et al., 1992). In addition, there is a possibility that VEGF receptor expression may be modified by factors other than ovarian steroids, for example, cytokines or hypoxia (Patterson et al., 1996; Sharkey et al., 2000). These different expression patterns and regulation of flt- 1 and KDR indicate that they may play different roles in the regulation of endometrial function, as suggested by Smith (1998) and Waltenberger et al. (1994). 
Further studies are needed to determine their specific roles. In the present study, KDR was also localized in vascular smooth muscle cells. As there is a report that uterine smooth muscle cells express KDR and proliferate in response to VEGF (Brown et al., 1997), the VEGF system may be involved in the proliferation of vascular smooth muscle cells.

The present study raises the possibility that VEGF may regulate the function of endometrial stromal cells and glandular epithelial cells in an autocrine-paracrine manner, as VEGF receptors were expressed in those cells. It has been reported that VEGF receptors are expressed in a variety of non-endothelial cells (Ergun et al., 1997; Krüssel et al., 1999; Meduri et al., 2000; Sugino et al., 2000a; Möller et al., 2001) and that they are functional (Barleon et al., 1996; Clauss et al., 1996; Ahmed et al., 1997; Brown et al., 1997). It is of special interest to note that VEGF can act as a survival factor and inhibit apoptosis in endothelial cells (Spyridopoulos et al., 1997; Gerber et al., 1998). Recent evidence indicates that apoptosis may play an important role in the determination of the lifespan of decidual cells and glandular epithelial cells (Akcali et al., 1996; Kokawa et al., 1996, 1998; Dai et al., 2000). In addition, the redox system that may control apoptosis is present in human endometrium (Sugino et al., 1996, 2000b,c, 2001). The high expression of VEGF and its receptors in decidualized cells and glandular epithelial cells, and the upregulation of VEGF and KDR by oestrogen and progesterone indicate that VEGF may be involved in the prolongation of the lifespan of endometrial cells for successful pregnancy.

This work was supported in part by Grant-in-Aid for Scientific Research 11671623 and 13671721 from the Ministry of Education, Science, and Culture, Japan.

\section{References}

Ahmed A, Dunk C, Kniss D and Wilkes M (1997) Role of VEGF receptor-1 (Flt-1) in mediating calcium-dependent nitric oxide release and limiting DNA synthesis in human trophoblast cells Laboratory Investigation $\mathbf{7 6}$ 779-791

Akcali KC, Khan SA and Moulton BC (1996) Effect of decidualization on the expression of bax and $\mathrm{bcl}-2$ in the rat uterine endometrium Endocrinology 137 3123-3130

Athanassiades A, Hamilton GS and Lala PK (1998) Vascular endothelial growth factor stimulates proliferation but not migration or invasiveness in human extravillous trophoblast Biology of Reproduction 59 643-654

Barleon B, Sozzani S, Zhou D, Weich HA, Mantovani A and Marme D (1996) Migration of human monocytes in response to vascular endothelial growth factor (VEGF) is mediated via the VEGF receptor flt-1 Blood 87 3336-3343

Brown LF, Detmar M, Tognazzi K, Abu-Jawdeh G and Iruela-Arispe ML (1997) Uterine smooth muscle cells express functional receptors (flt-1 and KDR) for vascular permeability factor/vascular endothelial growth factor Laboratory Investigation 76 245-255

Chakraborty I, Das SK and Dey SK (1995) Differential expression of vascular endothelial growth factor and its receptor mRNAs in the mouse uterus around the time of implantation Journal of Endocrinology 147 339-352

Charnock-Jones DS, Sharkey AM, Rajput-Williams J, Burch D, Schofield JP, Fountain SA, Boocock CA and Smith SK (1993) Identification and localization of alternately spliced mRNAs for vascular endothelial growth factor in human uterus and estrogen regulation in endometrial carcinoma cell lines Biology of Reproduction 48 1120-1128

Charnock-Jones DS, Macpherson AM, Archer DF, Leslie S, Makkink WK, Sharkey AM and Smith SK (2000) The effect of progestins on vascular endothelial growth factor, oestrogen receptor and progesterone receptor immunoreactivity and endothelial cell density in human endometrium Human Reproduction 15 (Supplement 3) 85-95

Clauss M, Weich H, Breier G, Knies U, Rock W, Waltenberger J and Risau W (1996) The vascular endothelial growth factor receptor Flt-1 mediates biological activities Journal of Biological Chemistry $27117629-17634$

Dai D, Moulton BC and Ogle TF (2000) Regression of the decidualized mesometrium and decidual cell apoptosis are associated with a shift in expression of bcl2 family members Biology of Reproduction 63 188-195

Das SK, Chakraborty I, Wang J, Dey SK and Hoffman LH (1997) Expression of vascular endothelial growth factor (VEGF) and VEGF-receptor messenger ribonucleic acids in the peri-implantation rabbit uterus Biology of Reproduction 56 1390-1399

Ergun S, Kilic N, Fiedler W and Mukhopadhyay AK (1997) Vascular endothelial growth factor and its receptors in normal human testicular tissue Molecular and Cellular Endocrinology 131 9-20

Ferrara N and Davis-Smyth T (1997) The biology of vascular endothelial growth factor Endocrine Reviews 18 4-25

Gerber HP, Dixit V and Ferrara N (1998) Vascular endothelial growth factor induces expression of the antiapoptotic proteins $\mathrm{BCl}-2$ and $\mathrm{A} 1$ in vascular endothelial cells Journal of Biological Chemistry 27313 313-13 316

Graubert MD, Ortega MA, Kessel B, Mortola JF and Iruela-Arispe ML (2001) Vascular repair after menstruation involves regulation of vascular endothelial growth factor-receptor phosphorylation by sFLT-1 American Journal of Pathology 158 1399-1410

Greb RR, Bukowski R, Hsiu JG, Williams RF, Hodgen GD and Goodman AL (1995) Vascular endothelial growth factor (VEGF) in primate endometrium Annals of the New York Academy of Science 761 376-381

Greb RR, Heikinheimo O, Williams RF, Hodgen GD and Goodman LA (1997) Vascular endothelial growth factor in primate endometrium is regulated by oestrogen-receptor and progesterone receptor ligands in vivo. Human Reproduction 12 1280-1292

Hickey M and Fraser IS (2000) The structure of endometrial microvessels Human Reproduction 15 (Supplement 3) 57-66

Huang JC, Liu DY and Dawood MY (1998) The expression of vascular endothelial growth factor isoforms in cultured human endometrial stromal cells and its regulation by $17 \beta$-oestradiol Molecular Human Reproduction 4 603-607

Kashida S, Sugino N, Takiguchi S, Karube A, Takayama H, Yamagata Y, Nakamura $\mathbf{Y}$ and Kato H (2001) Regulation and role of vascular endothelial growth factor in the corpus luteum during mid-pregnancy in rats Biology of Reproduction 64 317-323

Klauber N, Rohan RM, Flynn E and D'Amato RJ (1997) Critical components of the female reproductive pathway are suppressed by the angiogenesis inhibitor AGM-1470 Nature Medicine 3 443-446

Kokawa K, Shikone T and Nakano R (1996) Apoptosis in the human uterine endometrium during the menstrual cycle Journal of Clinical Endocrinology and Metabolism 81 4144-4147

Kokawa K, Shikone T and Nakano R (1998) Apoptosis in human chorionic villi and decidua during normal embryonic development and spontaneous abortion in the first trimester Placenta 19 21-26

Krüssel JS, Casan EM, Raga F, Hirchenhain J, Wen Y, Huang HY, Bielfeld P and Polan ML (1999) Expression of mRNA for vascular endothelial growth factor transmembraneous receptors Flt-1 and KDR, and the soluble receptor sflt in cycling human endometrium Molecular Human Reproduction 5 452-458

Lau TM, Affandi B and Rogers PAW (1998) The effects of levonorgestrel implants on vascular endothelial growth factor expression in the endometrium Molecular Human Reproduction 5 57-63

Lebovic DI, Shifren JL, Ryan IP, Mueller MD, Korn AP, Darney PD and Taylor RN (2000) Ovarian steroid and cytokine modulation of human endometrial angiogenesis Human Reproduction 15 (Supplement 3) $67-77$ 
Li XF, Gregory J and Ahmed A (1994) Immunolocalisation of vascular endothelial growth factor in human endometrium Growth Factors 11 277-282

Macpherson AM, Archer DF, Leslie S, Charnock-Jones DS, Makkink WK and Smith SK (1999) The effect of etonogestrel on VEGF, oestrogen and progesterone receptor immunoreactivity and endothelial cell number in human endometrium Human Reproduction 14 3080-3087

Meduri G, Bausero P and Perrot-Applanat M (2000) Expression of vascular endothelial growth factor receptors in the human endometrium: modulation during the menstrual cycle Biology of Reproduction 62 439-447

Möller B, Rasmussen C, Lindblom B and Olovsson M (2001) Expression of the angiogenic growth factors VEGF, FGF-2, EGF and their receptors in normal human endometrium during the menstrual cycle Molecular Human Reproduction 7 65-72

Nayak NR, Critchley HOD, Slayden OD, Menrad A, Chwalisz K, Baird DT and Brenner RM (2000) Progesterone withdrawal up-regulates vascular endothelial growth factor receptor type 2 in the superficial zone stroma of the human and macaque endometrium: potential relevance to menstruation Journal of Clinical Endocrinology and Metabolism 85 3442-3452

Noyes RW, Herting AT and Rock J (1950) Dating the endometrial biopsy Fertility and Sterility $13-25$

Patterson C, Perrella MA, Hsieh CM, Yoshizumi M, Lee ME and Haber E (1995) Cloning and functional analysis of the promoter for KDR/flk-1, a receptor for vascular endothelial growth factor Journal of Biological Chemistry 27023 111-23 118

Patterson C, Perrella MA, Endege WO, Masao Y, Lee ME and Haber E (1996) Downregulation of vascular endothelial growth factor receptors by tumor necrosis factor- $\alpha$ in cultured human vascular endothelial cells Journal of Clinical Investigation 98 490-496

Sharkey AM, Day K, Macpherson A, Malik S, Licence D, Smith SK and Charnock-Jones DS (2000) Vascular endothelial growth factor expression in human endometrium is regulated by hypoxia Journal of Clinical Endocrinology and Metabolism 85 402-409

Shifren JL, Tseng JF, Zaloudek CJ, Ryan IP, Meng YG, Ferrara N, Jaffe RB and Taylor RN (1996) Ovarian steroid regulation of vascular endothelial growth factor in the human endometrium: implications for angiogenesis during the menstrual cycle and in the pathogenesis of endometriosis Journal of Clinical Endocrinology and Metabolism 81 3112-3118

Smith SK (1998) Angiogenesis, vascular endothelial growth factor and the endometrium Human Reproduction Update 4 509-519

Spyridopoulos I, Brogi E, Kearney M, Sullivan AB, Cetrulo C, Isner JM and
Losordo DW (1997) Vascular endothelial growth factor inhibits endothelial cell apoptosis induced by tumor necrosis factor- $\alpha$ : balance between growth and death signals Journal of Molecular Cellular Cardiology 29 1321-1330

Sugino N, Shimamura K, Takiguchi S, Tamura H, Ono M, Nakamura Y, Ogino K, Uda T and Kato H (1996) Changes in activity of superoxide dismutase in the human endometrium throughout the menstrual cycle and in early pregnancy Human Reproduction 11 1073-1078

Sugino N, Zilberstein M, Srivastava RK, Telleria CM, Nelson SE, Risk M, Chou JY and Gibori G (1998) Establishment and characterization of a simian virus 40 -transformed temperature-sensitive rat luteal cell line Endocrinology 139 1936-1942

Sugino N, Kashida S, Takiguchi S, Karube Y and Kato H (2000a) Expression of vascular endothelial growth factor and its receptors in the human corpus luteum during the menstrual cycle and in early pregnancy Journal of Clinical Endocrinology and Metabolism 85 3919-3924

Sugino N, Kashida S, Takiguchi S, Nakamura Y and Kato H (2000b) Induction of superoxide dismutase by decidualization in human endometrial stromal cells Molecular Human Reproduction 6 178-184

Sugino N, Nakata M, Kashida S, Karube A, Takiguchi S and Kato H (2000c) Decreased superoxide dismutase expression and increased concentrations of lipid peroxide and prostaglandin F2 $\alpha$ in the decidua of failed pregnancy Molecular Human Reproduction 6 642-647

Sugino N, Karube-Harada A, Kashida S, Takiguchi S and Kato H (2001) Reactive oxygen species stimulate prostaglandin $\mathrm{F} 2 \alpha$ production in human endometrial stromal cells in vitro. Human Reproduction $\mathbf{1 6}$ 1797-1801

Tarantino S, Verhage HG and Fazleabas AT (1992) Regulation of insulinlike growth factor-binding proteins in the baboon (Papio anubis) uterus during early pregnancy Endocrinology 130 2354-2362

Torry DS, Harris G, Holt VJ, Caudle MR, Keenan JA and Torry RJ (1996) Vascular endothelial growth factor expression in cycling human endometrium Fertility and Sterility $\mathbf{6 6}$ 72-80

Waltenberger J, Claesson-Welsh L, Siegnahn A, Shibuya M and Heldin CH (1994) Different signal transduction properties of KDR and Flt-1, two receptors for vascular endothelial growth factor Journal of Biological Chemistry 26926 988-26 995

Received 9 August 2001.

First decision 20 September 2001.

Accepted 12 November 2001. 